\begin{tabular}{|c|c|c|c|}
\hline $\begin{array}{r}\text { Cod-liver oil........ } \\
\text { Average........ }\end{array}$ & $\begin{array}{c}\text { Total bromine. } \\
85.16-84.67 \\
84.91\end{array}$ & $\begin{array}{c}\text { Addition figure. } \\
84.52-84.09 \\
84.305\end{array}$ & $\begin{array}{c}\text { Substitution figure } \\
0.63-0.5^{8} \\
0.605\end{array}$ \\
\hline $\begin{array}{r}\text { Menhaden oil....... } \\
\text { Average....... }\end{array}$ & $\begin{array}{l}\text { I20.10-120.30 } \\
120.15\end{array}$ & $\begin{array}{l}\text { II } 8.88-118.93 \\
\text { I I } 8.905\end{array}$ & $\begin{array}{l}\text { I. } 22-I .27 \\
\text { I. } 245\end{array}$ \\
\hline $\begin{array}{l}\text { Sweet almond oil.... } \\
\text { Average....... }\end{array}$ & $\begin{array}{c}59.54-59.15 \\
59.345\end{array}$ & $\begin{array}{c}57 \cdot 3^{8-57.02} \\
57.20\end{array}$ & $\begin{array}{l}2.16-2.13 \\
2.145\end{array}$ \\
\hline $\begin{array}{r}\text { Sperm oil } \ldots . . \ldots \ldots \\
\text { Average....... } \\
\text { Castor oil } \ldots \ldots \ldots \ldots \\
\text { Average....... }\end{array}$ & $\begin{array}{c}54.6 \mathrm{I}-54.56 \\
54.585 \\
52.62-52.80 \\
52.7 \mathrm{I}\end{array}$ & $\begin{array}{c}52.4 I-52.2 I \\
52.3 I \\
50.09-50.07 \\
50.08\end{array}$ & $\begin{array}{l}2.20-2.34 \\
2.27 \\
2.53^{-2.73} \\
2.63\end{array}$ \\
\hline $\begin{array}{r}\text { Resin oil.......... } \\
\text { Average....... }\end{array}$ & $\begin{array}{l}108.67-109.23 \\
108.90\end{array}$ & $\begin{array}{l}6.74-6.47 \\
6.605\end{array}$ & $\begin{array}{l}\text { IOI. } 93-102.76 \\
\text { I02.345 }\end{array}$ \\
\hline
\end{tabular}

As will be seen upon examination, the foregoing table gives results differing widely from those of other experimenters. In cases where the substitution is small this is probably due, in part at least, to experimental error, as great care is necessary in the conduct of the operation. Errors are titrated for, along with substitution, and the result obtained is compounded of these two items. In connection with this investigation, the recent article of Marshall on the "Iodine Value of Oils" should also be noted.

Attention should also be called to the fact that several of the oils examined above were somewhat rancid and it is probably due to this fact that sweet almond oil shows substitution.

\title{
THE USE OF METALLIC SODIUM IN BLOWPIPE ANALYSIS.
}

\section{By Charles lathrop Parsons.}

Received !January 8 , I90I.

THE use of sodium carbonate to assist the action of the reduand is adopted by all text-books on the subject. The reducing action is partly due to the formation of sodium cyanide but more largely to the formation of gaseous sodium and carbon monoxide. At best its action is slow and nothing more severely tests the skill of the beginner than the attempt to obtain a button of metallic tin from cassiterite, or the sulphur reaction from gypsum. In general it is much more difficult to reduce an oxide or sulphide before the blowpipe, than it is to cause the opposite reaction to take place by means of the oxidizing flame.

${ }_{1}$ J. Soc. Chem. Ind., (1900), p. $2 \mathrm{r}_{3}$. 
Therefore, if the assay is not kept in the reducing zone of the flame a reoxidation will almost certainly take place.

The great reducing power of powdered aluminum has been well illustrated by Goldschmidt and Vautin, ${ }^{1}$ and, although the fact that this property is possessed also by magnesium and sodium has long been known, W. Hempel ${ }^{2}$ seems to have been the first to propose the use of the latter as a reagent in qualitative analysis. Hempel calls attention to the ease with which reduction may be brought about by sodium, but states that it does not give satisfactory results on charcoal. He recommends that the sodium be flattened out upon an ordinary filter-paper, and after being mixed with the powdered substance folded once and then rolled so that a double layer of paper is between each layer of sodium. This roll is next enclosed in a spiral of iron wire, set on fire in a Bunsen flame and cooled in the unburned gas below. It is next triturated with water in an agate mortar, and the residue carefully examined.

I have found these details to be quite unnecessary and that the reaction takes place with the greatest ease upon charcoal. To the operator who has been used to the much more tedious reduction with sodium carbonate the quickness and certainty of the result are almost startling, and the reduction takes place with silicates, chlorides, carbonates, borates, sulphates, sulphides, etc., with as much ease and accuracy as with the oxides themselves. The method is extremely simple.

A small piece of metallic sodium, not more than 3 or 4 mm. in diameter, is hammered out flat on some smooth surface. The substance to be reduced is powdered and spread upon it, pressed into the metal with the hammer and the whole turned and kneeded into a little ball with a knife blade. It is then placed upon a slight depression in a piece of charcoal and ignited with a match or the Bunsen flame. A momentary flash ensues, and the reduction is accomplished. The residue is now heated before the blowpipe, and as the sodium oxide and hydroxide immediately sink into the charcoal, any fusible metallic particles collect easily into a button and may be recognized in the usual manner. Volatile metals, like zinc, oxidize and yield with surprising readiness their characteristic coatings and on digging up

1 J. Soc. Chem. Ind., 17, $5+5$.

2Ztschr. anorg, Chem., 16, 22. 
a little of the charcoal, moistening with water and placing upon a silver coin, the "Hepar" reaction is obtained if sulphur was present in any form. It is perhaps superfluous to add that this last reaction is certain in its conclusions only when carried out upon a piece of charcoal uncontaminated by previous tests.

Applied to minerals the method yields results, but little less certain than when pure salts or oxides are reduced. Galenite yields at once a button of lead which in the oxidizing flame gives the lead coating without a trace of the white coating of sulphate which ordinarily results. Garnierite gives a residue of silicon and magnetic nickel to which the bead test can be immediately applied. Chrysocolla and cassiterite yield buttons of copper and tin respectively as readily as a button of lead is obtained from cerusite. Even chromite is immediately reduced, and if the residue is powdered the iron may be quite largely separated from the chromium by means of the magnet. Barite, celestite, and gypsum show with ease the sulphur reaction and the residue if moistened with hydrochloric acid gives the flame tests far more rapidly than if applied to the powdered minerals. In general the method is applicable whenever reduction can take place and whenever the reduced material yields characteristic reactions more readily than the mineral itself.

The metallic sodiun does not need to be kept under naphtha but may be supplied to a class in small rubber-stoppered widemouthed bottles. A lump of sodium two or three centimeters in diameter will keep for months in this manner with only superfcial oxidation. It must, of course, be carefully kept away from water or moisture. In rolling up the sodium and substance to be reduced into a ball, the metal should not be touched with the fingers for with one or two of the more easily reduced oxides or sulphides, the reaction sometimes begins spontaneously. This takes place quite readily with the peroxide of lead. Large quantities of sodium should be avoided or the reaction may become dangerously violent.

From my experience in its use with classes during the last two years, I feel sure that sodium will soon be universally employed as a reagent in blowpipe laboratories. 